DOI: https://doi.org/10.31933/dijemss.v2i4 Received: $10^{\text {th }}$ March 2021, Revised: $18^{\text {th }}$ March 2021, Publish: $18^{\text {th }}$ March 2021

\begin{tabular}{|c|c|c|}
\hline DINASTI & $\begin{array}{l}\text { DIJEMSS } \\
\text { DINASTI INTERNATIONAL JOURNAL } \\
\text { OF EDUCATION MANAGEMENT AND } \\
\text { SOCIAL SCIENCE }\end{array}$ & $\begin{array}{r}\text { https://dinastipub.org/DIJEMSS } \\
\text { editor@dinastipub.org } \\
08117401455\end{array}$ \\
\hline
\end{tabular}

\title{
THE INFLUENCE OF TRANSFORMATIONAL LEADERSHIPS AND ORGANIZATIONAL COMMITMENT TO TURNOVER INTENTION THROUGH JOB SATISFACTION AS A MEDIATOR
}

\author{
Lystia Tri Utami ${ }^{1}$, M. Havidz Aima ${ }^{2}$ \\ ${ }^{1)}$ Universitas Mercu Buana, Jakarta, Indonesia, lystia.tri@gmail.com \\ ${ }^{2)}$ Universitas Mercu Buana, Jakarta, Indonesia, havidz.aima@mercubuana.ac.id
}

\section{Corresponding Author: Lystia Tri Utami}

\begin{abstract}
This research aims to uncovered and evaluated those issues which related to the influences that appeared from transformational leadership and organizational commitment towards turnover intention through job satisfaction as a mediator at Operational Directorate employees of PT XYZ. The design which currently used in this research was causality analysis to revealed the connection between each variables. The population in this research was all the employees from Operational Directorate of PT. XYZ which amounted to 1084 employees. The sampling method was performed by simple random sampling with a total of 233 respondents. The data analysis method used SEM-PLS with the results showed that transformational leadership and organizational commitment had a positive and significant impact on job satisfaction. Transformational leadership has no affect towards turnover intention, but the organizational commitment and job satisfaction had a positive and significant impact on turnover intention. The transformational leadership and organizational commitment had a simultaneous impact towards job satisfaction. And the Transformational leadership, organizational commitment and job satisfaction had simultaneous impact towards turnover intention. Job satisfaction has fully mediates the affect which appears from transformational leadership and organizational commitment towards turnover intention.
\end{abstract}

Keywords: Transformational leadership, organizational commitment, job satisfaction, turnover intention.

\section{INTRODUCTION}

Maintaining the employee health is one of the benefits that company provides to the employees. Health maintenance management could be accomplished by the company directly or indirectly. If the company does not manage it directly then usually the company would leaves it to other parties such as health insurance or a third party administrator (TPA).

PT XYZ is a TPA company which combines the elements of technology and human resources in one of healthy claims management services, surely the human resources played 
an important role in analyzing medical expense reimbursement proposals which made by patients or health service providers. The ability to analyze which performed by humans is needed because of the variation in different cases handling. The analysis process start from verification and approval of the health reimbursement application which has costs were accomplished by HR who is work under the Operations Directorate. Therefore, the operational directorate of PT XYZ is an directorate which has the most number of employees with the highest frequent turnover.

According to the data which author gathered, the operational directorate's employee turnover has increased since June 2019, with the highest employee turnover occured in August 2019 by 69 employees or around 3.95\%. The estimation of the number of employee turnover from January to November 2019 was 493 people with an average percentage of $2.56 \%$. To discover further, the authors has conducted a pre-research to 30 employees at Operational Directorate of PT XYZ. And according to the pre-survey results, those 29 employees stated that they had thoughts of leaving the company. Besides that, the author also found that there are three main factors which are strongly suspected in influencing the turnover intention at the Operations Directorate employees of PT. XYZ, namely transformational leadership, organizational commitment and job satisfaction.

According to the phenomenon which occurred, thus the authors were decided to performed further research with the title of "The Influence of Transformational Leaderships and Organizational Commitment to Turnover Intention through Job Satisfaction as a Mediator".

\section{LITERATURE REVIEW}

\section{Transformational Leadership}

Robbins (2015) in Irnawati \& Prasetyo (2020) said that leadership is an ability to influence groups in order to achieving the goals. Quoted from Pradana, et al (2013) which stated that transformational leadership is a leadership style that used by managers if they want their groups to expand its boundaries and have performance beyond the organizational status quo. Meanwhile, the definition of transformational leaders itself are kind of leadership style who are teaches their followers to put their personal interests aside for sake of the organization and able to give a tremendous impact on their followers (Robbins \& Judge, 2008:90). Bass and Avolio (1990) in Yukl (2017:316) were identified the transformational leadership behavior in four components namely idealized influence, inspirational motivation, intellectual stimulation and individualized consideration.

\section{Organizational Commitment}

Sopiah (2017:157) has defined that commitment as an psychological attached which occured within the employees towards the organization which could be identified by a strong trust and acceptance of the organization's goals and values. According to Kaswan (2012:293) The employee commitment is a measure of an employees' willingness to stay with the company in the future. According to Robbins \& Judge (2008:100) in Prasetyo, et al (2021) organizational commitment is an condition in which an employee sides to the organization and its goals and wants to defend itself as part of its members of the organization. Mayer, et 
al (1998) in Sopiah (2017:157) suggested that there are three components in organizational commitment, namely: affective commitment, continuous commitment and normative commitment.

\section{Job Satisfaction}

According to Sunyoto (2013:15) job satisfaction is an pleasant or unpleasant feeling within the employees towards their work. While based on Noe, et al (1997:23) in Fajarto, et al (2019) stated that job satisfaction is an pleasant feeling which resulting from the perception that someone's job has fulfills the value of its important work. The characteristics and challenges which arise in their work could revealed by the satisfaction of its employee (Luthans, 2008:431). According to Mathis \& Jackson (2013:158) which stated that there are several dimensions that could be used in order to measure job satisfaction, such as the job itself and another aspects of salary, recognition/relations with coworkers, supervisoremployee relations and promotions/an opportunities for advancement.

\section{Turnover Intention}

Mathis \& Jackson (2011:159) in Sulistiyono \& Aima (2020) argued that turnover is an process when employees leaves an organization. According to Aydogdu \& Asikgil (2011) turnover intention could be referred as an behaviour to leave the company while turnover itself could be mean by an actual separation between the employee and the company. Mobley (2011:15) stated that turnover intention as the tendency or desired from the employees to quit their job voluntarily or move from one workplace to another according to their own will. Kaenmeyer-Mueller \& Wanberg (2003) in Hermansyah (2017) were explained that there are two types of employee behavior which describe the employees' plan to leave the company, namely work withdrawal and searching behaviour.

\section{Prior Research}

Eliyana, et al (2019) who found that transformational leadership had a positive and significant impact on job satisfaction. Kerdngern \& Thanitbenjasith (2017) were also found that the employee commitment had a positive and significant impact on job satisfaction. Meanwhile, Sucihati \& Dayatullah (2019) stated that transformational leadership and organizational commitment had a negative and significant impact on job satisfaction. Hakim \& Ibrahim (2017) who seen that transformational leadership and job satisfaction had a negative and significant impact towards turnover intention. While research from Prasetyo, et al (2021), and Nurfadilah, et al (2018) who found that organizational commitment had a negative and significant impact towards turnover intention. Meanwhile, Mayora \& Purwanto (2019) who found that transformational leadership had a positive and significant impact towards Turnover intention. Furthermore, Prasetya \& Dewi (2019) were explained that the transformational leadership style has none impact towards the Turnover intention. Setiawan \& Harahap (2016) found that organizational commitment and job satisfaction had a positive and significant impact on turnover intention. Puspa, et al (2018) found that transformational leadership and employee commitment were capable to improved the employees' job satisfaction at PT Bank Mandiri. Abouraia \& Othman (2017) showed that transformational 
leadership, employee commitment and job satisfaction had a simultaneous impact on turnover intention.

\section{Theoretical Framework and Hypothesis}

According to the background, the research purposed, theoretical research and its previous research which has been mentioned above, thus the theoretical framework and hypothesis in this research could be drawn as follows:

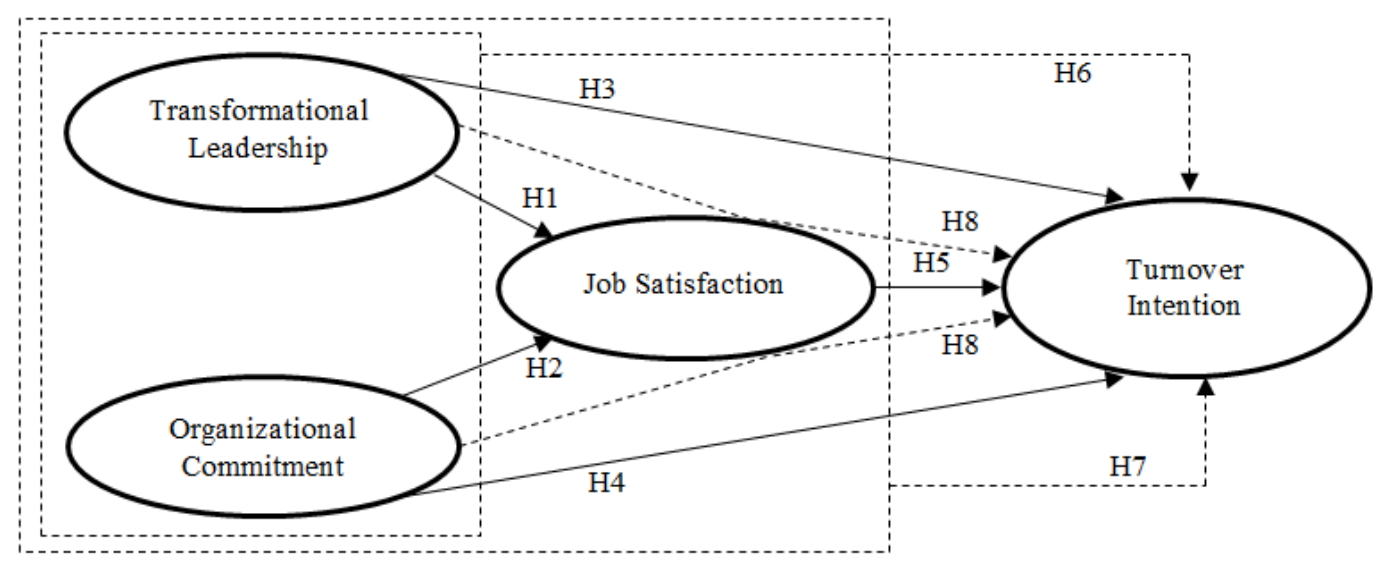

Figure 1. Theoretical Framework

H1: Transformational leadership had an affect to the job satisfaction.

$\mathrm{H} 2$ : Organizational commitment had an affect to the job satisfaction.

H3: Transformational leadership had an affect to the turnover intention.

H4: Organizational commitment had an affect to the turnover intention.

H5: Job satisfaction had an affect to the turnover intention.

H6: Transformational leadership and organizational commitment had an simultaneous affect on job satisfaction.

H7: Transformational leadership, organizational commitment and job satisfaction had an simultaneous affect on turnover intention.

H8: Job satisfaction has capable to played its role in mediating the impact which caused by transformational leadership and organizational commitment on turnover intention.

\section{RESEARCH METHODS}

This research took quantitative method as its method through causality model to find out causal correlations between the variables. The independent variables in this research are transformational leadership and organizational commitment. Meanwhile, the research dependent variable was job satisfaction and turnover intention. The population in this research was all employees at Operational Directorate from PT. XYZ which amounted of 1084 employees. The sampling method was performed through simple random sampling with a total of 233 respondents (Slovin, 5\% error tolerance). Data collection techniques in this research was an literature reviews, interviews and questionnaires. The data analysis method that used was an SEM-PLS through the SmartPLS 3.2.8 tool to analyzed the research hypothesis. 


\section{FINDINGS AND DISCUSSION}

\section{Respondent Characteristics}

According to the research results, the majority of respondents in this research were women (79.9\%), this highly caused the majority of positions which occupied by employees at PT. XYZ as an claim department staff needed precision and patience to process an underwriting and claim verification. Has an ages between 26-35 years (63.9\%), this might cause at PT XYZ requires an employees who have high levels of productivity. Having an undergraduate education (46.5\%), this cause of the new employee recruitment program which implemented at PT XYZ has decided that the lowest level is Bachelor Degree. Have a work period of $\geq 5$ years $(45.6 \%)$, this caused at PT XYZ for the past 1 year did not recruited any new employees and has been focusing on developing the existing employees who have been worked for almost $\geq 5$ years.

\section{Descriptive Statistical Analysis}

According to the descriptive analysis results from this research, it was found that the respondents' perceptions of transformational leadership and organizational commitment were quite high with mean values of 3.50 and 3.85. Meanwhile, the respondents' perceptions relate to job satisfaction and turnover intention were high with mean values of 4.11 and 4.10.

\section{Outer Model Test}

According to the convergent validity analysis, the loading factor value from the indicators of transformational leadership, organizational commitment, job satisfaction and also turnover intention has a values range of 0.660 to 0.974 so it was declared valid (>0.600).

According to the analysis of cronbach's alpha score and the composite reliability, the research variables (transformational leadership, organizational commitment, job satisfaction and turnover intention) had a value range was $0.934-0.973$ so they were all declared reliable $(>0.700)$.

\section{Inner Model Test}

According to the path analysis results which examine through SmartPLS bootstrapping, the following results that obtained could be seen as follows:

Table 1. Path Coefficient Value and P-Values (Direct Effect)

\begin{tabular}{|l|c|c|c|c|c|}
\hline & $\begin{array}{c}\text { Original } \\
\text { Sample (O) }\end{array}$ & $\begin{array}{c}\text { Sample } \\
\text { Mean (M) }\end{array}$ & $\begin{array}{c}\text { Standard } \\
\text { Deviation } \\
\text { (STDEV) }\end{array}$ & $\begin{array}{c}\text { T Statistics } \\
(\mid \mathrm{O} / \text { STDEVD }\end{array}$ & $\begin{array}{c}\text { P } \\
\text { Values }\end{array}$ \\
\hline $\begin{array}{l}\text { Transformational Leadership > Job } \\
\text { Satisfaction }\end{array}$ & 0.136 & 0.139 & 0.054 & 2.501 & 0.013 \\
\hline $\begin{array}{l}\text { Organizational Commitment -> Job } \\
\text { Satisfaction }\end{array}$ & -0.020 & -0.019 & 0.032 & 0.624 & 0.533 \\
\hline $\begin{array}{l}\text { Transformational Leadership >> } \\
\text { Turnover Intention }\end{array}$ & 0.703 & 0.701 & 0.047 & 14.902 & 0.000 \\
\hline $\begin{array}{l}\text { Organizational Commitment -> } \\
\text { Turnover Intention }\end{array}$ & 0.151 & 0.150 & 0.054 & 2.802 & 0.005 \\
\hline $\begin{array}{l}\text { Job Satisfaction > Turnover } \\
\text { Intention }\end{array}$ & 0.777 & 0.780 & 0.050 & 15.607 & 0.000 \\
\hline
\end{tabular}


The structural equation of this research could be formulated as follows:

Job Satisfaction $(\mathrm{Y})=0.136 \mathrm{X} 1+0.703 \mathrm{X} 2$

Turnover Intention $(\mathrm{Z})=-0.020 \mathrm{X} 1+0.151 \mathrm{X} 2+0.777 \mathrm{Y}$

1) Transformational leadership has an impact value of 0.136 towards job satisfaction with a t-statistic value of 2.501 along with a p-value of 0.013 . So it could be interpreted that transformational leadership has a positive and significant impact on job satisfaction.

2) Organizational commitment has an impact value of 0.703 towards job satisfaction with a t-statistic value of 14.902 along with a p-values of 0.000 . So it can be interpreted that organizational commitment has a positive and significant impact on job satisfaction.

3) Transformational leadership has an impact of -0.020 on turnover intention with a tstatistic value of 0.624 along with a p-values of 0.533 . So it could be interpreted that transformational leadership has no significant affect on turnover intention.

4) Organizational commitment has an impact value of 0.151 towards turnover intention with a t-statistic value of 2.802 along with a p-values of 0.005 . So it could be interpreted that organizational commitment has a positive and significant affect on turnover intention.

5) Job satisfaction has an impact value of 0.777 towards turnover intention with a t-statistic value of 15.607 along with a p-values of 0.000 . So it could be interpreted that job satisfaction has a positive and significant affect on turnover intention.

Indirect effect test outcomes that would explained in Table 3 below:

Table 2. Path Coefficient Value and P-Values (Indirect Effect)

\begin{tabular}{|l|c|c|c|c|c|}
\hline & $\begin{array}{c}\text { Original } \\
\text { Sample (O) }\end{array}$ & $\begin{array}{c}\text { Sample } \\
\text { Mean (M) }\end{array}$ & $\begin{array}{c}\text { Standard } \\
\text { Deviation } \\
\text { (STDEV) }\end{array}$ & $\begin{array}{c}\text { T Statistics } \\
(\mid \mathrm{O} / \mathrm{STDEV})\end{array}$ & $\begin{array}{c}\text { P } \\
\text { Values }\end{array}$ \\
\hline $\begin{array}{l}\text { Transformational Leadership -> Job } \\
\text { Satisfaction - Turnover intention }\end{array}$ & 0.106 & 0.109 & 0.044 & 2.397 & 0.017 \\
\hline $\begin{array}{l}\text { Organizational Commitment -> Job } \\
\text { Satisfaction -> Turnover intention }\end{array}$ & 0.546 & 0.547 & 0.049 & 11.112 & 0.000 \\
\hline
\end{tabular}

According to the indirect effect results, it could be illustrated that:

1) The impact from transformational leadership on turnover intention through job satisfaction was 0.106. Because the indirect effect was greater than the direct effect, it could be said that job satisfaction has fully mediates its influence of transformational leadership to turnover intention.

2) The impact from organizational commitment on turnover intention through job satisfaction was 0.546. Because the indirect effect was greater than the direct effect, thus it could be concluded that job satisfaction has fully mediates its influence of organizational commitment towards turnover intention.

\section{$\mathbf{R}^{\mathbf{2}}$ Evaluation, F-Test, GoF, and Predictive Relevance $\left(\mathbf{Q}^{\mathbf{2}}\right)$}

The $\mathrm{R}^{2}$ value from the job satisfaction variable was 0.643 and the $\mathrm{R}^{2}$ value from the turnover intention variable was 0.792 . The $\mathrm{R}^{2}$ value was indicates that the level of determination from the exogenous variables (transformational leadership and organizational commitment) on the endogenous variables was quite high. 
The F-test result shows that the F-count value from the job satisfaction variable was 162 and the F-count value from the turnover intention variable was 364.46 at an alpha level of 0.05. This means that F-count > F-table, then $\mathrm{H} 6$ and $\mathrm{H} 7$ were accepted.

The calculation of the Goodness of Fit Index (GoF) result shows that it has value of 0.687 or $>0.36$, so it could be interpreted that the mixed performance from the measurement model (outer model) and the structural model (inner model) as a whole was quite good.

According to the calculation of predictive relevance $\left(Q^{2}\right)$, it shows its value of 0.926 or in other words, the value of $\mathrm{Q}^{2}>0$, so that it proved that this model has good predictive relevance.

\section{Inter-Dimensional Correlation Analysis}

Just quoted from the inter-dimensional correlation test results, it could be concluded that:

1) In transformational leadership variable towards job satisfaction variable, the highest relations was occured in inspirational motivation dimension to the promotion dimension, which is 0.566 . While the lowest correlation dimension in this variable was the individual consideration dimension to the salary dimension, which is only 0.362 .

2) In transformational leadership variable towards turnover intention variable, the highest relations was occured on idealized influence dimension towards the work withdrawal dimension, which is 0.512 . Meanwhile, the lowest correlation dimension was occured in the dimension of intellectual stimulation to the dimension of searching behaviour, which is only 0.370 .

3) In the variable organizational commitment to the job satisfaction variable, the highest correlation dimension occured in continuance commitment towards the dimensions of the supervisor-employee relations which amounted to 0.806. Meanwhile, the lowest correlation dimension on this variable is the dimension of affective commitment to the recognition dimension, which is 0.606 .

4) In the organizational commitment variable towards turnover intention variable, the highest correlation dimension occured in the continuance commitment dimension to the work withdrawal dimension which is 0.762 . Meanwhile, the lowest correlation dimension in this variable occured in the dimension of affective commitment to the dimension of searching behaviour, which is only 0.576 .

5) In the job satisfaction variable towards the turnover intention variable, the highest correlation dimension occured in the dimension of recognition towards the work withdrawal dimension which amounted to 0.889 . Meanwhile, the lowest correlation dimension in this variable happened in the dimension of the job itself to the level of searching behaviour which is only 0.699 . 
Table 3. Inter-Dimensional Correlation Analysis

\begin{tabular}{|c|c|c|c|c|c|c|c|c|c|}
\hline \multirow[t]{2}{*}{ Variable } & \multirow[t]{2}{*}{ Dimension } & & \multicolumn{5}{|c|}{ Job Satisfaction ( $\mathrm{Y}$ ) } & \multicolumn{2}{|c|}{$\begin{array}{c}\text { Turniover } \\
\text { Intention }(\mathrm{Z})\end{array}$} \\
\hline & & & Y.1 & $\mathrm{Y}, 2$ & Y.3 & $\mathrm{Y} .4$ & $\mathrm{Y} .5$ & Z.1 & Z.2 \\
\hline \multirow{4}{*}{$\begin{array}{l}\text { Transformational } \\
\text { Leadership (X1) }\end{array}$} & Idealized Influence & $\mathrm{X} 1.1$ & $.526^{21}$ & $.544^{* 12}$ & $.481^{*}$ & $.504^{24}$ & $.562^{x+2}$ & $.512^{m}$ & $.413^{20}$ \\
\hline & Inspirational Motivation & $\mathrm{X} 12$ & $.494^{* *}$ & $.508^{* *}$ & $.503^{* *}$ & $.497^{* *}$ & $.566^{\prime \prime \prime}$ & $.491^{* *}$ & $.395^{* *}$ \\
\hline & Intellectual Stimulation & $\mathrm{X} 13$ & $471^{-}$ & $.365^{* *}$ & $.363^{* *}$ & $.429^{-}$ & $357^{* *}$ & $.432^{* *}$ & $.370^{\circ "}$ \\
\hline & Individual Consideration & $\mathrm{X} 1.4$ & $.468^{-7}$ & $.362^{r 7}$ & $.436^{* *}$ & $449^{-}$ & $.422^{* *}$ & $.459^{* *}$ & $382^{* *}$ \\
\hline \multirow{3}{*}{$\begin{array}{c}\text { Organizational } \\
\text { Commitment } \\
(\mathrm{X} 2)\end{array}$} & Affective Commitment & $\mathrm{X} 2.1$ & $.652^{24}$ & $.606^{m r}$ & $.611^{\pi r}$ & $.691^{27}$ & $.623^{x-1}$ & $.664^{2 x}$ & $.576^{77}$ \\
\hline & Continuance Commitment & $\mathrm{X} 2.2$ & $.775^{* *}$ & $.719^{* *}$ & $.722^{* *}$ & $.806^{* \prime}$ & $.737^{* *}$ & $.762^{* *}$ & $.677^{* *}$ \\
\hline & Normative Commitment & $\mathrm{X} 23$ & $.711^{-}$ & $.646^{*-}$ & $.704^{* *}$ & $.761^{-}$ & $.716^{\circ-}$ & $.708^{* *}$ & $.661^{*}$ \\
\hline \multirow{5}{*}{$\begin{array}{l}\text { Job Satisfaction } \\
\text { (Z) }\end{array}$} & Job itself & Y.1 & & & & & & $.790^{\circ+0}$ & $.699^{\circ}$ \\
\hline & Salary & Y. 2 & & & & & & $.855^{* *}$ & $.712^{* *}$ \\
\hline & Recognition & Y. 3 & & & & & & $.886^{* *}$ & $.743^{*-}$ \\
\hline & $\begin{array}{l}\text { Supervisor-employee } \\
\text { relations }\end{array}$ & Y.4 & & & & & & $.889^{* *}$ & $.772^{* *}$ \\
\hline & Promotion & $\mathrm{Y} .5$ & & & & & & $.867^{* *}$ & $.721^{* *}$ \\
\hline
\end{tabular}

\section{Discussion}

The transformational leadership variable had a positive and significant impact on job satisfaction variable, the higher the level of transformational leadership, would increase the job satisfaction and vice versa. These results are common with the research by Hakim \& Ibrahim (2017). According to Robbins \& Judge (2008:90), the transformational leaders are kind of leadership who gave their followers direction to put their personal interests aside for the sake of the organization and were capable to have an tremendous influence on their followers. The conditions in the field shows that most of the leaders from the supervisor level to the manager have played a role in providing direction to solving problems in operations and increasing the employee confidence through motivation and has resulting in a positive reaction to the work done by the employee.

The organizational commitment variable had a positive and significant impact on the job satisfaction variable, thus the higher the organizational commitment, has resulted in the higher the job satisfaction will be and so it does conversely. These results were based on the research which conducted by Kerdngern \& Thanitbenjasith (2017). According to Allen \& Meyer (2001) in Busro (2018:74) argues that commitment is an relative strength in individuals to identifying and engaging in organizations. The conditions on the field, employees who survive and which have a sense of obligation to remain at the company it shows an active role of employees both in their work and in company activities.

The transformational leadership variable has no significant affect on the turnover intention variable. This means that transformational leadership shown to employees has no significant effect on employee turnover intention. These results were consistent with research conducted by Prasetya \& Dewi (2019). In the managerial implications that occur, not all leaders has used the transformational leadership. There are still have a leaders who are not firm in making decisions so it has an impact in raising doubt feelings from the employees to their leaders. Surely this condition becomes an X factor for employees to think about finding another job in somewhere else. 
The organizational commitment variable has a positive and significant affect on turnover intention variable, thus it says that the higher the employee commitment, the higher the employee turnover intention and conversely. These results were similiat to the research from Setiawan \& Harahap (2016). The employees of PT. XYZ still has a commitment to remain at the company consedering that their lives would be disrupted if the employees tried to leaves the Company. This reason is not enough to keep employees stays at the company, because the employees still realize if they leaving the company they should be find another place which has the conditions equal to what they expected for.

The job satisfaction variable has a positive and significant affect on the turnover intention variable, thus the higher the employees' job satisfaction, the higher the employee turnover intention will be and vice versa. These results are in accordance with research from Setiawan \& Harahap (2016). The conditions on the field, are even create the employees who have been in middle management positions, still have the desire to leave the company. This desire is due to new, better opportunities outside the company and job demands from superiors which exceed the employee limits which has impact to the desire of employees to leaves the companies.

The transformational leadership and organizational commitment variables has simultaneously positive and significant affect on job satisfaction variable with a simultaneous influence was $64.30 \%$, while the remaining $35.70 \%$ from the employee job satisfaction of PT. $\mathrm{XYZ}$ was determined by other factors outside the variables Thus, the higher the level of transformational leadership and employee commitment, the higher the job satisfaction will be and so it does conversely. This according to the research by Puspa, et al (2018) who found that transformational leadership and organizational commitment simultaneously impact in a positive and significant towards job satisfaction.

The transformational leadership, organizational commitment, and job satisfaction variable had simultaneously impact to the turnover intention variable with a simultaneous influence value was $79.20 \%$. These results was illustrated that $79.20 \%$ of turnover intention which occured at PT. XYZ employees was influenced by transformational leadership, organizational commitment and job satisfaction, while the remaining of $20.80 \%$ from turnover intention at PT. XYZ was influenced by factors outside the variables. This is strengthen the research from Abouraia \& Othman (2017) which showing that the transformational leadership, employee commitment and job satisfaction had an simultaneous effect towards turnover intention.

The path coefficient value from the direct influence of transformational leadership on the upright turnover intention was -0.0202 which equal to 0.0004 < the path of coefficient value from the indirect effect of transformational leadership on turnover intention was 0.106 , so it could be illustrated that job satisfaction has fully mediates (full mediation) the indirect effect of transformational leadership on turnover intention. The path coefficient value of the direct effect of organizational commitment on upright turnover intention was 0.1512 , which equal to 0.0228 < the path of coefficient value from the indirect effect of organizational commitment on turnover intention was 0.546 , so it could be said that the job satisfaction has fully mediates the indirect affect from organizational commitment to turnover intention. 


\section{CONCLUSION AND SUGGESTION \\ Conclusion}

Elicited from the research and discussion above, these following conclusions could be conveyed as follows:

1) Transformational leadership had a positive and significant affect on job satisfaction through the dimension of inspirational motivation as being the strongest one.

2) Organizational commitment had a positive and significant affect on job satisfaction through the dimension of continuous commitment as being the strongest one.

3) Transformational leadership did not have a significant affect on turnover intention.

4) Organizational commitment had a positive and significant affect on turnover intention through the dimension of continuous commitment as being the strongest one.

5) Job satisfaction had a positive and significant affect on turnover intention, through the dimension of the supervisor-employee relations as being the strongest one.

6) Transformational leadership and organizational commitment had a positive and significant affect on job satisfaction

7) Transformational leadership, organizational commitment and job satisfaction had simultaneously affect on turnover intention.

8) Job satisfaction had fully mediates the affect which caused by transformational leadership and organizational commitment to turnover intention.

\section{Suggestions}

According to these analysis results from the discussion and some of the conclusions above, the suggestions that could be made up as an complement to these research results are:

1) Management needs to provide rewards such as employee of the year each department.

2) The Leaders on the middle management level need to increase their personal rewards in form of verbally recognition to the work that has been accomplished by the employees.

3) Immediately process the vacant positions which are still available.

4) Optimize the tiring of decision making at the management level, so that the problems will respond to more quickly, precisely and minimal risk.

5) Evaluate the workload and job characteristics of each department.

6) Dividing the job according to the characteristics which is more detailed and organized.

7) Adding the supervisors to play an active role in providing the positive responses to the work done by the employees

8) Providing a leadership communication training to leaders from supervisor level and assistant manager level.

\section{REFERENCES}

Abouraia, M.K., \& Othman, S.M. (2017). Transformational Leadership, Job Satisfaction, Organizational Commitment, and Turnover Intentions: The Direct Effects among Bank Representatives. American Journal of Industrial and Business Management, 7, 404-423. 
Aydogdu, S., \& Asikgil, B. (2011). An empirical study of the relationship among job satisfaction, organizational commitment and turnover intention. International Review of Management and Marketing, 1(3), 43-53.

Busro, M. (2018). Teori-Teori Manajemen Sumber Daya Manusia. Prenada Media. Jakarta.

Eliyana, A, Ma'arif, S., \& Muzakki, M. (2019). Job Satisfaction and Organizational Commitment Effect in the Transformational Leadership towards Employee Performance. European Research on Management and Business Economics, 144-150.

Fajarto, S.P., Aima, M.H., \& Karsono, B. (2019). The Effect of Compensation and Job Satisfaction on Increasing Productivity of Asuransi Jasindo Head Office Employees Mediated by Motivation Variable. International Journal of Innovative Science and Research Technology, 4(7), 100-113.

Hakim, A.H.L, \& Ibrahim, H.M. (2017). Transformational leadership and turnover intention: Mediating role of overall job satisfaction. Journal of Tourism, Hospitality \& Culinary Arts, 9(2), 237-248.

Hermansyah, Y. (2017). Pengaruh Kepemimpinan, Kompensasi dan Pengembangan Karir Terhadap Turnover Intention Pada Karyawan Kantor Pusat PT. XYZ Tbk. S2 Thesis, Universitas Mercu Buana Jakarta.

Irnawati, J.E., \& Prasetyo, J.H. (2020). The Influence Over the Transformational of Leadership Style, the Organizational Culture, and Employee Empowerment towards Achievement of Organizational Strategies in one the Central Government Organization. International Journal of Innovative Science and Research Technology, 5(3), 917-927.

Kaswan. (2012). Manajemen Sumber Daya Manusia untuk Keunggulan Bersaing Organisasi. Graha Ilmu. Yogyakarta.

Kerdngern, N., \& Thanitbenjasith, P. (2017). Influence of contemporary leadership on job satisfaction, organizational commitment, and turnover intention: A case study of the construction industry in Thailand. International Journal of Engineering Business Management, 9, 1-8.

Luthans, F. (2008.) Organizztional Behavior. McGraw-Hill Companies, Inc. New York.

Mathis, R.L., \& Jackson, J.H. (2013). Human Resource Management. South-Western Cengage Learning.

Mayora, M., \& Purwanto, E. (2019). Pengaruh Transformational Leadership dan Kepemimpinan Otentik Terhadap Niat Keluar Karyawan Dengan Mediasi Komitmen Afektif. Journal of Business and Applied Management, 12(2), 155-201.

Mobley, W.H. (2011). Pergantian Karyawan: Sebab, Akibat dan Pengendaliannya. Alih Bahasa: Nurul Imam. PT Pustaka Binaman Pressindo. Jakarta.

Nurfadilah, N., Aima, M.H., \& Havidz, S.A.H. (2018). The Impact of Compensation and Leadership on The Organizational Commitment and The Implication on Employee's Turnover Intention of PT Provices Indonesia Central Office. International Humanities and Applied Sciences Journal, 1(1).

Pradana, M.A., Sunuharyo, B.S., \& Djamhur, H. (2013). Pengaruh Gaya Transformational Leadership dan Transaksional Terhadap Kinerja Karyawan (Studi Pada Karyawan Tetap PT. Mustika Bahana Jaya, Lumajang). Jurnal Administrasi Bisnis, 4(1), 1-11. 
Prasetya, P.W.Y, \& Dewi, I.G.A.M. (2019). Pengaruh Gaya Transformational Leadership Terhadap Turnover Intention Dimediasi Oleh Job Satisfaction pada Karyawan. E-Jurnal Manajemen, 8(4), 2042-2070.

Prasetyo, J.H., Ariawan, J., \& Ariyanto, E. (2021). An Excellent Strategy in Reducing Turnover Intention at Permata Keluarga Bekasi Hospital. International Journal of Scientific \& Technology Research, 10(01), 162-168.

Puspa, D.Y., Nur, H.M., Lumban, T.D.S.K., \& Lelly, H.S.S.W. (2018). The Influence of Transformational Leadership, Organizational Culture and Organizational Commitment on Employee Satisfaction of PT Bank Mandiri (Persero), Tbk of Jember Area. RJOAS, 4(76).

Robbins, S.P., \& Judge, T.A. (2008). Perilaku Organisasi Edisi ke-12. Salemba Empat. Jakarta.

Setiawan, D.P., \& Harahap, P. (2016). Pengaruh Organizational Commitment, Kompensasi, dan Karakteristik Pekerjaan Terhadap Turnover Intention Dengan Job Satisfaction Sebagai Variabel Intervening (Studi pada PT. Sido Muncul Semarang). Jurnal Riset Ekonomi dan Bisnis, 9(3).

Sopiah. (2017). Perilaku Organisasi. Andi Offset. Yogyakarta.

Sulistiyono, D., \& Aima, M.H. (2020). The Influence of Career Development and Compensation on Work Satisfaction and Its Implications against Turnover Intention at AJB Bumiputera 1912's Head Office. Dinasti International Journal of Education Management and Social Science, 2(1), 81-95.

Sucihati, S., \& Dayatullah, D. (2019). Pengaruh Gaya Kepemimpinan Trasnformasional dan Koitmen Organisasi Terhadap Kinerja Karyawan Dengan Job Satisfaction Sebagai Variabel Intervening. Jurnal Ekonomi dan Publik, 15(2).

Sunyoto, D. (2013). Teori, Kuesioner, dan Proses Analisis Data Perilaku Terhadap Kinerja Individual. Universitas Katolik Widya Mandala Madiun.

Yukl, G. (2017). Kepemimpinan Dalam Organisasi (Edisi 8). Indeks. Jakarta. 